\title{
Muriella australis J. Phillipson (Chlorophyta), a new species for the algal flora of Bulgaria
}

\author{
Ivan Kirilov Kiryakov ${ }^{1}$ \& Katya Naneva Velichkova ${ }^{2}$ \\ 1 Department of Botany, Paisiy Hilendarski University of Plovdiv, Plovdiv, Bulgaria. \\ 2 Department of Biology and Aquaculture, Agricultural Faculty, Trakia University, Stara Zagora, Bulgaria
}

\section{Correspondence}

K.N. Velichkova

E-mail: genova@abv.bg

Received: 18 Jaunary 2015

Accepted: 29 May 2015

Published on-line: 23 July 2015

\section{Resumen}

Muriella australis J. Phillipson (Chlorophyta), una nueva especie para la flora de algas de Bulgaria

Se cita una nueva especie de alga para Bulgaria. Esta rara especie (sólo conocida su locus classicus de Australia, aislada de suelo) se ha encontrado también en los montes Rópode, en la capa aerofílica del lecho de las fuentes de la villa de Slaveyno (provincia de Smolyan). Se ha extendido la diagnosis de la especie. Se ha realizado una revisión de la especie y del género.

Palabras clave: Muriella, Nueva cita, Algas raras, Bulgaria.

\begin{abstract}
A new species and genus Muriella australis for the algal flora of Bulgaria are reported in this article. This rare species (known only from locus classicus in Australia, isolated from soil) was discovered also in Rhodope Mountains, Bulgaria in aerophilic coating on the bed of the fountains in village Slaveyno (Smolyan district). The diagnosis of the species was extended and expanded. A review of the species to the genus concerned was accomplished.
\end{abstract}

Key words: Muriella, New record, Rare algae, Bulgaria.

\section{Introduction}

Six species belong to the genus Muriella Petersen: Muriella aurantica Vischer, Muriella australis J. Phillipson, Muriella magna Fritsch et John, Muriella decolor Vischer, Muriella zofingiensis (Dönz) Hindak and Muriella terrestris Petersen.

Later, some species have dropped out of the genus. This was the case with Chlorella zofingiensis Dönz., which Hindak (1982) added to the genus under the name Muriella zofingiensis (Dönz) Hindak. Afterward, Kalina \& Punčochářová (1987) argued for the transfer this species to the genus Mychonastes Simpson \& Van Valkenburg, based on their observations from scanning electron microscopy. Fučíková \& Lewis (2012), however, resurrected the genus Chromochloris Kol \& F.Chodat and relate M. zofingiensis to the synonyms of Chromochloris zofingiensis (Dönz) Fučíková \& Lewis and proposed the transfer of M. zofingiensis to the genus Chromochloris.

According to Hindák (1982), M. aurantiaca Vischer was synonymized with $M$. zofingiensis (Dönz) Hindák, but it has since been demonstrated that $M$. aurantiaca belongs to a separate chlorophycean genus, Pseudomuriella Hanagata 
(Hanagata 1998, Fučíková et al. 2011).

The species $M$. terrestris is polytypic. It is relatively uncommon. So far, it has been reported only in Southern Europe: Italy (soil; pine forest in Brixen, South Tyrol), Croatia (soil in Lavsa Island). Two forms of it were described: f. majculata Broady and f. major Bourrelly, as well as var. reticulata Broady known only from its classical field Vestfold Hills, Antarctica, isolated from amongst moss plants with an abundant epiphytic growth of Nostoc sp. (Bourrelly 1966, Broady 1982).

The species $M$. decolor is a typical aerophytic alga but, in Antarctica, it was found for the first time growing in a soil habitat (Andreeva 1998).

According to Andreeva (1998), the species $M$. magna is also of unknown status. But according to other authors, the species belongs to the genus Chromochloris (Day et al. 1995, John \& Tsarenko 2002, Tsarenko 2011).

M. australis was described by Phillipson (1935) in Australia and New Zealand. Its classical field is in the Victoria state where it was isolated from soil (aerophilic form) (Komárek \& Fott 1983, Day et al. 1995, Ettl \& Gärtner 1995, Andreeva 1998).

The object of the manuscript is to describe the morphological characteristics of Muriella australis J.Phillipson, which is a newly found species for the algal flora of Bulgaria.

\section{Material and Methods}

We came upon this very rare and interesting algae on 27.10.2012. It was evolving among aerophilic coating on the concrete bed of "Kumchovska fountain" in the village Slaveyno $\left(41^{\circ} 37{ }^{\prime} 52.72 \mathrm{~N}\right.$, $\left.24^{\circ} 51^{\prime} 43.55^{\prime \prime} \mathrm{E}\right)$, Rhodope Mountains, located about 1050 masl.

The coating, which is constantly wet from the spray of the water flowing from the fountain, was grass green. The dominant species in that coating was the filamentous green alga Klebsormidium crenulatum Kütz. As subdominants we identified three types from Cyanophyta: two filamentous Oscillatoria sp., Lyngbya sp., and a cocal Gloeocapsa sp. Very rarely cells of Staurastrum sp. (Chlorophyta) were observed.

Studies were conducted on living material from the field immediately after collection (time from 28.10 to 10.11 .2012 ). The collected material (13 samples) was examined on a light microscope Olympus CX31 at the Department of Biology and Aquaculture at the Trakia University.

Morphological features were recorded on the basis of this alga material and relevant literature sources (Komárek \& Fott 1983, Ettl \& Gärtner 1995).

In this coating, M. australis was thoroughly developed represented by both vegetative and reproductive cells-forming autospores.

\section{Results}

Since the diagnosis made by the author of the species is very brief, and presented iconography (Phillipson 1935) represents only globular cells, we believe that the diagnosis should be further completed with data from the population of the village Slaveyno (Smolyan), Bulgaria.

Young cells (and autospores) were slightly oval or ovoid, and the old ones were globular.

The autospores were 10-13 X 7-11 $\mu \mathrm{m}$ of size and they had (3)-4-(5) chloroplasts. The size of old cells was 10-21 $\mu \mathrm{m}$, some of them forming autospores reached $29 \mu \mathrm{m}$, which exceeded by far those in the diagnosis (Phillipson 1935). According to Komarek \& Fott (1983) the cells are spherical with parietal disc-shaped chloroplast. In our samples, most of the old cells contained up to 13 (rarely more) chloroplasts with polygonal borders, arranged close to the wall (Fig. 1A). The cells were uninucleate. The cell wall was smooth, and become thicker in old cells. In some cells, a bubble swelling of the wall, described by Phillipson, resulting from the peeling of the outer layer (Fig. 1B) was found. In the population from Bulgaria, the species also reproduced by autospores. Their number was usually 8 , but there were findings with 2-4, and rarely 16 autospores (Fig. 1C).

Most species of the genus Muriella were isolated from soil (Ettl \& Gärtner 1995, Andreeva 1998), so aerophilic algal coating is a new type of habitat for the species discussed in this article.

\section{Acknowledgements}

The authors are grateful to Mr. Dimitar Lazhov for the help in correcting the manuscript. 
A

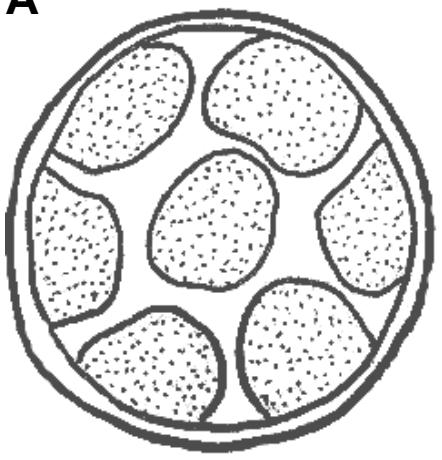

B

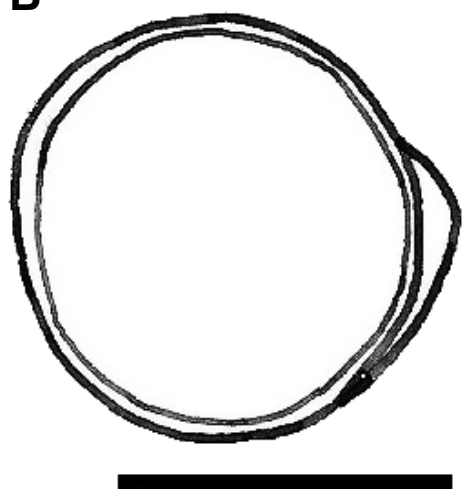

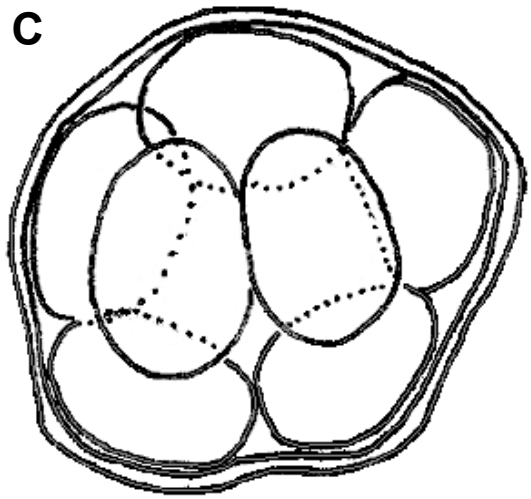

Figura 1. Muriella australis. A: Célula vegetativa con cloroplastos; B: Abultamiento en la pared; C: Autoesporas en célula reproductora. Barra de escala: $20 \mu \mathrm{m}$.

Figure 1. Muriella australis. A: Vegetative cell with chloroplasts; B: Bubble swelling of the wall; C: Autospores in reproductive cell. Scale bar $20 \mu \mathrm{m}$

\section{References}

Andreeva VM. 1998. Terrestrial and aerophilic green algae (Chlorophyta: Tetrasporales, Chlorcoccales, Chlorosarcinales). Sankt-Peterburg: Nauka

Bourrelly P. 1966. Les algues d'eau douce. Initiation á la sistematique I. Les algues vertes. Paris: N. Boubée.

Broady PA. 1982. New record of chlorophycean microalgae cutures from Antartic terrestrial habitats. Nova Hewigia 6: 445- 484.

Day SA, Wickham RP, Entwisle TJ \& Tyler PA. 1995. Bibliographic check-list of non-marine algae in Australia. Flora of Australia Supplementary Series 4: 1276.

Ettl H \& Gärtner G. 1995. Syllabus der Boden- Luft- und Flechtenalgen. Stuttgardt: Gustav Fisher.

Fučíková K, Rada J \& Lewis L. 2011. The tangled taxonomic history of Dictyococcus,Bracteacoccus and Pseudomuriella (Chlorophyceae, Chlorophyta) and their distinction based on a phylogenetic perspective. Phycologia 50: 422-429.

Fučíkova K \& Lewis L. 2012. Intersection of Chlorella, Muriella and Bracteacoccus: Resurrecting the genus Chromochloris Kol et Chodat (Chlorophyceae, Chlorophyta). Fottea 12: 83-93.

Hanagata N. 1998. Phylogeny of the subfamily Scotiellocystoideae (Chlorophyceae) and related taxa inferred from $18 \mathrm{~S}$ ribosomal RNA gene sequence data. Journal of Phycology 34: 1049-1054.
Hindák F. 1982. Taxonomic position of the chlorococcal alga Chlorella zofingiensis Dönz1934 (Chlorophyceae). Algological Studies 40: 13-23.

John DM \& Tsarenko PM. 2002. Order Chlorococcales. In: The Freshwater Algal Flora of the British Isles. An identification guide to freshwater and terrestrial algae (John DM, Whitton BA, Brook AJ, eds). Cambridge: Cambridge University Press, pp. 327-409.

Kalina T. \& Punčochářová M. 1987. Taxonomy of the subfamily Scotiellocystoideae Fott 1976 (Chlorellaceae, Chlorophyceae). Algological Studies 45: 473-521.

Komárek J. \& Fott B. 1983. Chlorophyceae (Grünalgen), Ordnung Chlorococcales. In: Das Phytoplankton des Sübwassers. Systematik und Biologie 16. (HuberPestalozzi G, ed.). Stuttgart: E. Schweizerbart Science Publishers, pp: 1-1044.

Massalski A., Mroziiiska T. \& Olech M. 2001. Ultrastructural observations on five pioneer soil algae from ice denuded areas (King George Island, West Antarctica). Polar Bioscience: 14, 61-70.

Phillipson J. 1935. Some algae from Victoria soils. Proceedings of the Royal Society of Victoria 47: 262287.

Tsarenko P. M. 2011: Trebouxiophyceae. In: Algae of Ukraine: diversity, nomenclature, taxonomy, ecology and geography. Volume 3: Chlorophyta (Tsarenko PM, Wasser SP \& Nevo E, eds). Ruggell: A.R. Gantner Verlag KG, pp. 61-108 